\title{
The effects of coaching in employees and organizational performance: The Spanish Case
}

\author{
Pedro Núñez-Cacho Utrilla ${ }^{1}$, Félix Angel Grande ${ }^{1}$, Daniel Lorenzo ${ }^{2}$ \\ ${ }^{1}$ Universidad de Jaén, ${ }^{2}$ Universidad de Cádiz (Spain) \\ pnunez@ujaen.es, fagrande@ujaen.es,daniel.lorenzo@uca.es
}

Received December, 2014

Accepted March, 2015

\begin{abstract}
Purpose: The expansion of coaching in firms reflects its potential use as a tool to improve the development of human capital and of the firm itself. Nevertheless, research into the effects of coaching is lagging some way behind practice and there is a need to establish a theoretical framework capable of explaining how the coaching process proceeds and its outcomes. The goal of this research is to analyze the effects of coaching in both, employees development, and organizational performance. Thus, we extend Joo's (2005) conceptual model by adding social exchange theory and the resource-based view, so as to to develop a model that allow us to investigate coaching.
\end{abstract}

Design/methodology/approach: We test our model on a sample of 498 Spanish firms. The hypotheses were analyzed using structural equations modeling.

Findings: Our results confirm that coaching has an influence on both individual performance and organizational performance indicators. Besides, social exchange theory and the resource-based view, are a proper frameworks so as to study the effects of coaching.

Practical implications: Coaching also helps firms to improve their competitive position. maximise benefits and minimise costs. We highlight several tips for practitioners in order to develop properly coaching processes. 
Originality/value: Coaching helps firms improve their competitive position via effects on organisational performance, sales increases and productivity growth.

Keywords: Coaching, resource-based view, social exchange theory

Jel Codes: 015

\section{Introduction}

In this complex and challenging business world, managing human capital is undoubtedly critical to a firm's success (Gurav \& Muldakar, 2011; Núñez-Cacho \& Grande, 2012). Thus, businesses are continuously seeking opportunities to improve their competitiveness. Coaching is one of many different human resource development practices that can help firms create an advantageous position with respect to competitors. In fact, Diedrich (1996) and McCracken and Heaton (2012) recognise the importance of coaching for employees and firms, viewing the practice as an important tool for career development. A growing number of businesses use coaching (Barlett, 2007; Chong, 2008; Moen \& Allgood, 2009; Richard, Taylor, Barnett \& Nesbit, 2002) because the practice responds to the needs and demands of the workplace (Sherman \& Freas, 2004) and is also effective in other ways, such as correcting and improving poor performance (Gravina \& Siers, 2011) or conflict resolution in the workplace (Anderson, Rayner \& Schyns, 2009). Moreover, coaching can be used to accelerate career learning (Parker, Hall \& Kram, 2008) or to ensure sustainable leadership (Boyatzis, Smith \& Blaine, 2006).

Nevertheless, despite the growing popularity of coaching and their supporters' claim that the practice helps improve performance in both employees and organisations, the literature offers little empirical evidence regarding the effects of this practice (Agarwal, Angst \& Magni, 2009). Thus, there is a need to explore this process and its effects empirically (Gray, Ekinci \& Goregaokar, 2011a). This lack of evidence raises doubts regarding whether the substantial investment in such programmes is justified. Researchers must also investigate the conditions guaranteeing its effectiveness and determine whether firms implementing this practice are following the optimal procedures. Most studies on this topic lack a theoretical framework, which reflects the immaturity of the body of research on the subject. The largest gap in the existing literature involves the coaching approaches that explain how this coaching works (Segers, Vloeberghs, Henderick \& Inceoglu, 2011). Thus, if we can show that coaching can improve firm performance, then human resource managers would be able to justify using the practice. In this case, coaching would be a best practice that improves organisational performance regardless of other internal or external factors (Ely \& Zaccaro, 2010; Huselid, 1993). 
Consequently, the aim of this article is to provide theoretical support to justify the use of employee coaching as part of human resource development and the effects of such coaching on workers and organisations. We also seek to determine whether our theoretical approaches are verified by testing the empirical model in a Spanish case. Achieving this objective may help bring empirical knowledge of coaching to a level that is more consistent with its popularity. Thus, our work will help bridge the current gap in the theoretical framework and justify the use of coaching as part of human resource development. The current work emphasises the importance of this line of research; the scarcity of previous research, as Carey, Phillippon and Cummings (2011) argue; and the need to further our knowledge of the effects of coaching. Furthermore, as Feldman and Lankau (2005) highlight, few theoretical studies examine how and why coaching should work and under which conditions it translates into greater organisational effectiveness.

Therefore, the main contribution of this work is that it improves our knowledge of coaching and its primary features. Moreover, we analyse its effects on employees and firms and identify the factors that can influence the effectiveness of this type of coaching. With regard to practical implications, this research offers valuable guidance to help managers assess the desirability of investing in coaching and orient the planning of their firms' human resources strategy.

To achieve our objectives, we have structured this paper as follows. After this introductory section, the remainder of this work is divided into five sections. Section 2 presents the conceptual framework within which we base the research and formulate our research hypotheses. In Section 3, we present the methodology that we follow as well as the sample. Section 4 presents the results of the research, and Section 5 provides a discussion of the results, limitations and future areas of research. The work ends with the main conclusions.

\section{Theoretical framework and hypotheses}

\subsection{Definition of coaching}

The literature offers many definitions of coaching. According to Kampa-Kolesch and Anderson (2001), coaching is a form of systematic feedback intervention that is designed to enhance professional skills, interpersonal awareness and personal effectiveness, whereas Peterson (1994) considers coaching to be a process that equips people with the tools, knowledge (Gil \& Carrillo, 2013) and opportunities that they need for professional development and to increase their effectiveness. 
On the other hand, Colomo and Casado (2006) define coaching as a guided, structured and continuously monitored improvement process that brings a participant closer to the preestablished optimum performance level for one's current function in an organisation. These authors essentially view coaching as a conversation between two parties-a coach and a coachee-in a productive, results-oriented context. Although different coaching definitions have been offered, there is some agreement regarding the core of coaching practices, and most definitions concur that coaching is a process that involves a series of one-to-one interactions between a manager and a coachee (Bono, Purvanova, Owler \& David, 2010). Alternatively, Feldman and Lankau (2005) argue that coaching relationships involve one-to-one counselling regarding work-related issues, use 360-degree feedback and propose improvements in the effectiveness of one's current position.

Additionally, Hannafey and Vitulano (2013) explain that coaching is a partnership between a management-level client and a coach hired by an organisation to assist the employee in becoming a more effective and successful manager. It was also highlighted its usefulness in the socialization of employees by Saks and Gruman (2011). Thus, we can state that coaching is a process designed by an organisation that involves two parties-a coach and a coachee-and that aims to correct performance work-related problems and to improve the coachee's skills and capabilities to assist in career development. We use this definition in the current work.

\subsection{Conceptual model}

After our diagnosis of the current state of the coaching research, we now develop a conceptual model in the following stages: antecedents and preparation, process implementation, shortterm outcomes and long-term outcomes.

\subsubsection{Preparation and implementation of coaching process}

In the preparation stage, a coach must follow a series of guidelines to ensure the effectiveness of the process. For example, the organisation must facilitate the execution of the process and identify the needs of its employees because by serving these needs, the firm will establish the objectives of the programme and analyse the behaviours during the process to transform those behaviours that are found to be negative. The firm can then adapt the coaching process to suit the characteristics of each participant. The integrity of the participants will also have an influence on the effectiveness of the process. 
When the firm decides to implement a coaching process, it must first establish clear objectives for doing so. These objectives include helping the coachee to focus his or her career and life (Jones \& Spooner, 2006). For this purpose, the firm will define goals and will control and verify how they are met to ensure that the coachee's action and decision making gain a proactive orientation. Thus, through the coaching process, firms seek to develop professional competencies to achieve objectives that they have previously established and to strengthen coachees to ensure that they make the appropriate changes during the process to guarantee its success.

\subsubsection{Process implementation}

After the preparation stage, the next stage involves conducting the process. Two participants take part in the process: the coach, who teaches, trains or guides the coachee in his/her current job (Evered \& Selman, 1989), and the coachee, the target of the relationship, who develops the knowledge and competences to improve professionally. The core of this coaching relationship is the on-the-job learning process, in addition to other possible issues, such as confidentiality questions, conflicts of interest, questions regarding professional standards, success measurement issues and financial matters (Hannafey \& Vitulano, 2013).

As Hutchinson and Purcell (2010) argue, many coaches are unsatisfied with the process because they need active support from firms in terms of providing recognition, timing and role clarity. Backes-Glelner and Tuor (2010) highlight the importance of a quality work climate for the success of human resource practices. Thus, to understand the implementation stage, it is necessary to consider a number of points that are important for the success of the coaching process. For example, the coach not only manages the coaching process but also can be a consultant who helps the coachee to implement innovations in procedures (McCracken \& Wallace, 2000), who adapts the coachee's skills and knowledge to the existing systems in the organisation, and who encourages the coachee to assimilate the firm's values and attitudes. The organisation must be aware of the abilities, skills and experience of the coach (Gray, Ekinci and Goregaokar, 2011b). Moreover, the coach commits to the coachee in a collaborative alliance to establish and clarify the objectives, to develop a plan of action to help the coachee achieve these objectives (Zeus \& Skiffington, 2002), and to reproach the coachee if he/she fails to fulfil previously accepted commitments. The coachee, in turn, must find the coach to be a valuable partner with whom he/she can share ideas, plans and strategies. The coachee can then evolve and gain a longer-term vision of questions that arise.

To ensure the effectiveness of the coaching process, the coach must have a deep knowledge of the coachee's job and of how the job relates to the objectives of the organisation. The coach 
must be willing and able to share information with the coachee and must be ready to dedicate the time that the process demands. For the process to proceed correctly, the relationship between the coach and coachee must be based on trust, consistent with the organisational climate, as highlighted by Shih, Chiang and Chen (2012). Success can also be influenced by other factors, such as the type of personal relationship that the coach and coachee establish and the harmony, connection and affinity between them (Hodgetts, 2002; Wanberg, Welsh \& Hezlett, 2003).

As noted above, to ensure that the coaching process is effective, both the coach and coachee must make efforts to achieve a number of objectives. The coach must be sufficiently qualified and experienced; must know the organisation well; and must be willing to transmit knowledge, dedicate time to the process and reproach the coachee when he/she does not perform as agreed. The coachee, in turn, must be committed to the process and must seek a good partner in the coach by sharing ideas and strategies and trusting the coach.

According to Cropanzano and Mitchell (2005), from social exchange theory the coaching relationship is reciprocal. The parties establish a normative framework within which to work. The success of the process will depend on several reasons: the confidentiality within the process; the consistency of the status of both coach and coachee; and their integrity, rationality, altruism and commitment.

Many empirical studies agree on this point and consider coaching to be effective because it offers employees an intense way of learning that is suited to their individual needs and thus leads to greater career satisfaction (Colomo \& Casado, 2006; Rowold \& Schilling, 2006; Sherman \& Freas, 2004; Zaleska \& De Menezes, 2007). The support of other organisational members, such as line managers, is also necessary (Leisink \& Knies, 2011). Likewise, Moen and Allgood (2009) note that this practice makes participating managers more efficient and effective in their leadership roles, as employee performance will improve if the coaching process is prepared and implemented properly. Nevertheless, a review of the literature also shows that scholars have not yet reached a consensus regarding the effectiveness of this practice (Bowles, Cunningham, De la Rosa \& Picano, 2007). Thus, we present our hypotheses:

Hypothesis 1: Organisational support improves the individual performance of a firm's human resources.

Hypothesis 2: Coaching improves the individual performance of a firm's human resources. 


\subsubsection{Process outcomes}

We consider it necessary to complement the Joo's (2005) framework, with a theoretical approach that supports the individual outcomes or results and that links these outcomes with organisational benefits. Social exchange theory is one of the most influential conceptual paradigms for understanding employee behaviour in the workplace (Cropanzano \& Mitchell, 2005). The central premise of this theory is that the exchange of resources is a fundamental form of interaction between the people participating in the coaching process because they expect the benefits that they obtain from the process to exceed the direct costs (Cook \& Emerson, 1978; Emerson, 1962).

In this way, Gouldner (1960) emphasises the following three aspects: first, the relationship is reciprocal because transactions flow in both directions because of the mutual exchange that the coach and coachee establish; second, this reciprocity is an expectation that both the coach and coachee share, each with his/her own particular situation; and third, reciprocity also becomes a moral norm of action throughout the coaching process. Cook and Emerson (1978) add a fourth aspect: in the exchange process that they establish, participants must negotiate the normative framework that will regulate the coaching relationship and in which they will detail their aims. Finally, a number of other aspects affect coaching outcomes, including rationality, altruism, group gain, status consistency among participants and competition (Cropanzano \& Mitchell, 2005).

Applying the theoretical approach discussed above, we observe that during the coaching relationship, a mutual exchange emerges between the coach and coachee following a set of pre-established norms and within which the coach and coachee will perceive a series of benefits that outweigh the costs of the process. Because social exchange theory describes the elements that emerge within the coaching relationship (Hammervoll, 2011; Tepper \& Taylor, 2003), this theory proves to be a useful framework not only to study the coaching process but also to analyse the outcomes or results of the process.

Social exchange theory helps explain the benefits that individuals perceive. Consequently, the next task is to identify these outcomes or results, including the benefits and costs of the process to the coach and coachee and the final outcome. Among the benefits of the coaching process, the coach and coachee become more satisfied with their careers in their organisation and perceive a positive effect on their lives. The process helps them to develop their skills, gives them more confidence, and improves their motivation as the reason or reasons one has for acting or behaving in a particular way (Lotfizadeh, Edwards \& Poling, 2014) and task performance. This technique also helps the coach to diagnose performance problems and to 
make the decisions necessary to resolve such problems. Thus, coaching can assist managers in evaluating employee performance.

Clearly, the need to coordinate and connect resources and capabilities renders human resources fundamental as an extremely important element of a firm's strategy (Lorenzet, Cook \& Ozeki, 2006). Nevertheless, to consider human resource strategic assets capable of generating competitive advantages according to the RBV, we must first verify that coaching confers strategic value on human resources; in other words, we must confirm that coaching renders human resources a valuable, rare, sustainable and inimitable resource (Amit \& Schoemaker, 1993; Barney, 1991; Grant, 1996; Peteraf, 1993).

According to the theory of resources and capabilities, coaching can give human resources strategic value because the practice renders this asset rare and more inimitable, thus transmitting a firm's strategy to individual employees and helping them understand the firm's mission and values (Núñez-Cacho, Grande \& Pedrosa, 2012; Pérez, Montes \& Vázquez, 2006). Thus, the competencies, capabilities and knowledge that are transferred in coaching programmes, which are designed to serve a firm's needs, have the potential to create resources that are capable of generating a sustainable competitive advantage (Barney, 1991).

On the basis of the above discussion, the following theoretical framework of our research is presented (Figure 1):

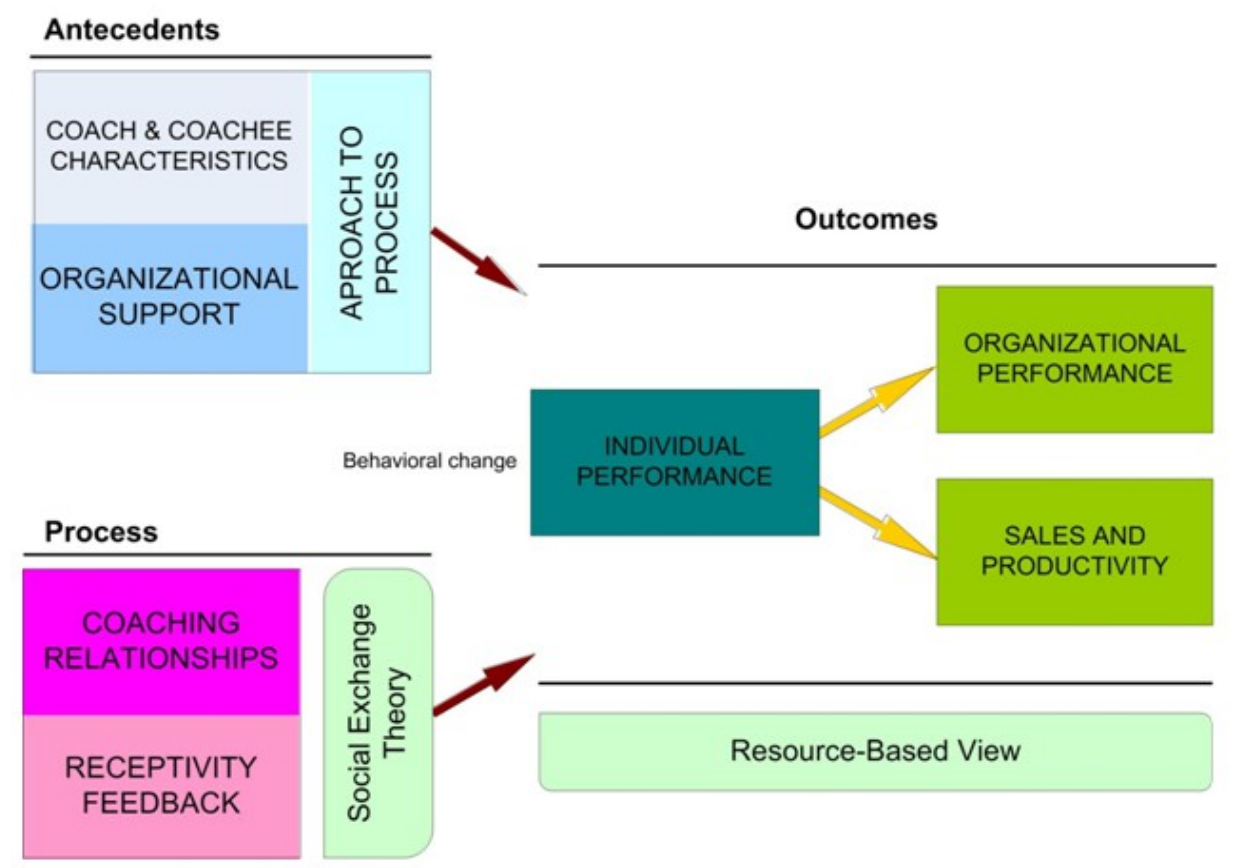

Figure 1. Theoretical framework for study of coaching. Source: The Authors, adapted from Joo (2005) 
Thus far, we have analysed the state of the art in coaching, completed the conceptual framework and established the theoretical framework to provide support for these processes according to social exchange theory and the RBV. We now conduct the empirical research of the theoretical questions formulated above.

When an organisation prepares for this process after previously identifying employee needs, establishing objectives, and supporting and facilitating the process execution (Bolch, 2001), there is a transmission of knowledge and competences that improve the individual performance of coachees. Coaching is a tool that is capable of creating value (Hammervoll, 2011) that consequently improves the capabilities of human resources. Coaching converts human resources into an asset that is unique and valuable to the organisation and that is difficult for competitors to imitate. As Ellinger, Ellinger and Keller (2003) and Luthans and Peterson (2003) highlight, a coachee will apply his/her new knowledge to daily tasks in his workplace, affecting positively his individual performance. As a consequence, we can expect that organisational performance improve. However, to ensure that this outcome actually occurs in practice, we must first empirically demonstrate the relationship between individual performance and organisational performance and thus avoid making inferences from one level to another. Such inferences frequently lead to the so-called fallacies of the wrong level (Allen, Smith, O'Shea, Mael \& Eby, 2009).

The various studies that identify a positive relationship between improvements in individual performance as a result of coaching practices and organisational performance use productivity to measure organisational performance (Birdi et al., 2008; Combs, Hall, \& Ketchen, 2006; Patterson \& West, 2004). However, Datta, Guthrie and Wright (2005) perceive some limitations of this measure and recommend complementing productivity with other indicators, such as profitability or growth in turnover. On the basis of the above discussion, the remaining hypotheses of this work are presented as follows:

Hypothesis 3: Improvements in individual performance as a result of coaching have a positive effect on firm performance.

Hypothesis 4: Improvements in individual performance as a result of coaching have a positive effect on firm growth. 
Figure 2 presents the hypotheses of the research model.

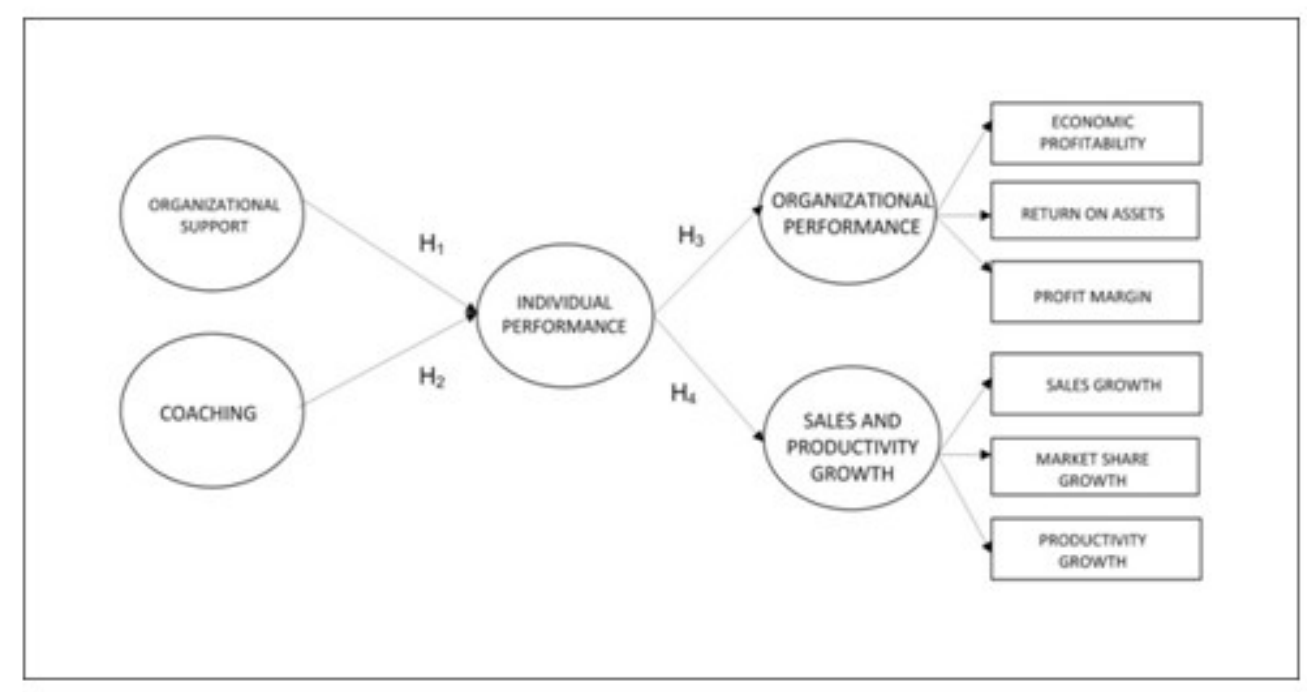

Figure 2. Research Model

\section{Methodology, sample and scales}

\subsection{Sample}

We sent 2,303 questionnaires to human resource managers of Spanish firms. To collect the information that we needed to complete our research, firms were selected at random from the database of the Spanish Business Register. We obtained a response rate of $21.6 \%$; thus, the final sample consisted of 498 firms. The confidence level of the sample is $95 \%(z=1.96)$, and the sampling error is $3.9 \%$.

\subsubsection{Control variables}

The mean firm size in terms of number of workers is 174 , and the mean firm age is 35 years old. We used these two variables-size and age-as control variables. The sectors of the sample firms are as follows: industry (39\%), commerce and services (37\%), and primary sector (24\%). Fully $91 \%$ of the sample firms formally program coaching processes. 


\subsection{Measurement scales: dimensionality and validity}

We designed a questionnaire on the basis of the literature review to obtain the information that we needed to resolve our research problems. In the development of the variable measurement scales, we used previous works as a reference and adapted the content to the specifics of our research. A group of experts then examined the different scale items to verify their suitability. With regard to the individual construct reliability, we first used the Cronbach's alpha coefficient and the composite reliability index of each construct. Second, to confirm the dimensionality of the scales, we conducted an exploratory factor analysis to examine the suitability of the groupings of variables around the corresponding dimensions. Finally, we verified the validity using a confirmatory factor analysis (CFA) of each construct.

\subsubsection{Organisational support and antecedents}

The variables that were used to build the organisational support and antecedent construct were drawn from the works of Salinero and Muñoz (2007) and Chand and Katou (2007). The results of the exploratory factor analysis are as follows. The first variable of this factor is "Are individual training and development needs analysed?" This variable has a weight of 0.756 . The second variable is "Does the company attempt to improve the skills and knowledge of employees?", and the weight of the factor is 0.718 . The third variable is "Are coaching and training plans essential for the company?" The weight of the factor for this variable is 0.641 . The fourth variable is "Does this process occur regularly?", with a weight of 0.757 . The fifth variable, "Does the number of coaching programmes increase every year?", has a weight of 0.692. The sixth variable is "Does the company have a detailed written training plan?", with a weight of 0.782 . Finally, the seventh variable is "Does the company evaluate the results of the process?", with a weight of 0.707 . The variance explained by the seven variables is 52.281 , and the value of the KMO test is 0.888 . The reliability of this scale is $\alpha=0.772$, and $\rho=0.791$.

\subsubsection{Coaching}

We used three variables to build the coaching construct, which we borrowed, in unmodified form, from Olivero, Bane and Kopelman (1997) and Gould (1997). The first variable is "The organisation sometimes employs a personal coach to help workers improve their performance in a short-term process". This variable has a factor weight of 0.863 . The second variable is "Coaching processes are programmed by the organisation", with a weight of 0.886 . The third variable is "The coach comes from outside of the firm", which has a weight of 0.696 . The 
variance explained by the three variables is 67.131, and the value of the KMO test is 0.709 . With regard to the scale reliability, $\alpha=0.946$, and $\rho=0.954$.

\subsubsection{Individual performance of human resources}

We used variables from Chand and Katou (2007) and Huselid, Becker and Beatty (2005) to measure the individual performance of human resources: "The workers are committed to the organisation", with a weight of 0.755; "The workers achieve their individual objectives", with a weight of 0.912; and "The workers improve their efficiency", with a weight of 0.884 . The variance explained is 52.341 , and the value of the KMO test is 0.771 . The reliability of this scale is $\alpha=0.711$, and $\rho=0.725$.

\subsubsection{Organisational performance}

To build the performance factor, we used variables from Rutheford, Kuratko and Holt (2008) and Molina, Claver, Pereira and Tarí (2009). The first variable is "What is the firm's profitability?", with a weight of 0.895 . The second is "What is the rate of return on assets?", which has a weight of 0.960 . The third is "What is the profit margin?", with a weight of 0.869 . The variance explained is 71.56 , the value of the KMO test is 0.709 , the Cronbach's alpha is $\alpha=0.814$, and $\rho=0.801$.

\subsubsection{Sales and productivity growth}

We used three indicators from Carlson, Upton and Seaman (2006) to measure the effects of coaching on indicators of growth. The first variable is "Growth in sales in the past three years", with a weight of 0.878 . The second is "Productivity growth in the past three years", which has a weight of 0.774 . The third is "Growth in market share in the past three years", with a weight of 0.818 . The KMO test value for this factor is 0.775 , the variance explained is 68.23 , $\alpha=0.746$, and $\rho=0.771$.

\subsubsection{CFA of each construct}

To test the discriminant validity, we analysed the existing correlations between the dimensions that measure various factors. We noted that the value of the squared correlation coefficient did not exceed the variance extracted from the construct and that this variance is greater than 
0.5. Upon verifying these issues, we can assume that the scales have discriminant validity. The results of this analysis are shown in Table 1.

\begin{tabular}{|l|c|c|c|c|c|}
\hline \multicolumn{1}{|c|}{ CONSTRUCT } & $\begin{array}{c}\text { ORG. } \\
\text { SUPPORT }\end{array}$ & $\begin{array}{c}\text { E. } \\
\text { COACHING }\end{array}$ & $\begin{array}{l}\text { INDIV. } \\
\text { PERFOR. }\end{array}$ & $\begin{array}{c}\text { S. and. } \\
\text { ORGAN. } \\
\text { PERFOR. }\end{array}$ & $\begin{array}{c}\text { SROD. } \\
\text { PRROWTH }\end{array}$ \\
\hline ORG. SUPPORT & $\mathbf{0 . 7 7}$ & - & - & - & \\
\hline E. COACHING & 0.49 & $\mathbf{0 . 9 4}$ & - & - & \\
\hline INDIV. PERFOR. & 0.41 & 0.40 & $\mathbf{0 . 7 1}$ & - & \\
\hline ORGAN. PERFOR. & 0.36 & 0.44 & 0.31 & $\mathbf{0 . 8 1}$ & $\mathbf{0 . 7 7}$ \\
\hline $\begin{array}{l}\text { S. and PROD. } \\
\text { GROWTH }\end{array}$ & 0.26 & 0.38 & 0.38 & 0.33 & 0.81 \\
\hline Variance & 0.55 & 0.67 & 0.52 & 0.71 & 0.71 \\
\hline
\end{tabular}

Table 1. Correlation, and Cronbach's alpha (diagonal) for the scales

Overall, the scale has a reliability of $\alpha=0.711$ and $\rho=0.728$, which is satisfactory for exploratory studies, and the composite reliability index is consistent with recommendations from Bagozzi and Yi (1988). We completed a CFA of the five measurement scalesorganisational support and antecedents, coaching, individual performance of human resources, organisational performance, and sales and productivity growth-to assure the validity of each construct of our model. We performed evaluations using Satorra-Bentler scaled $\chi^{2}=171.3840$, with 151 degrees of freedom and $p=0.12263$. The other adjustment indices have the following values: $\mathrm{NNFI}=0.973, \mathrm{CFI}=0.976, \mathrm{IFI}=0.976$ and $\mathrm{MFI}=0.934$. Finally, the RMSEA error is $<0.03$. Moreover, all of the relationships are significant $(p=0.05)$. Therefore, the evaluation of the indices shows a good fit based on the accepted criteria (Kline, 2005).

\section{Results of causal model estimation}

With the information from the previous analyses, we proceeded to estimate the proposed model linking organisational support and coaching with individual employee performance as well as linking individual performance with organisational performance measures and sales increases with productivity growth. Having specified, identified and estimated the model, we present the results of the estimation in Figure 3. 


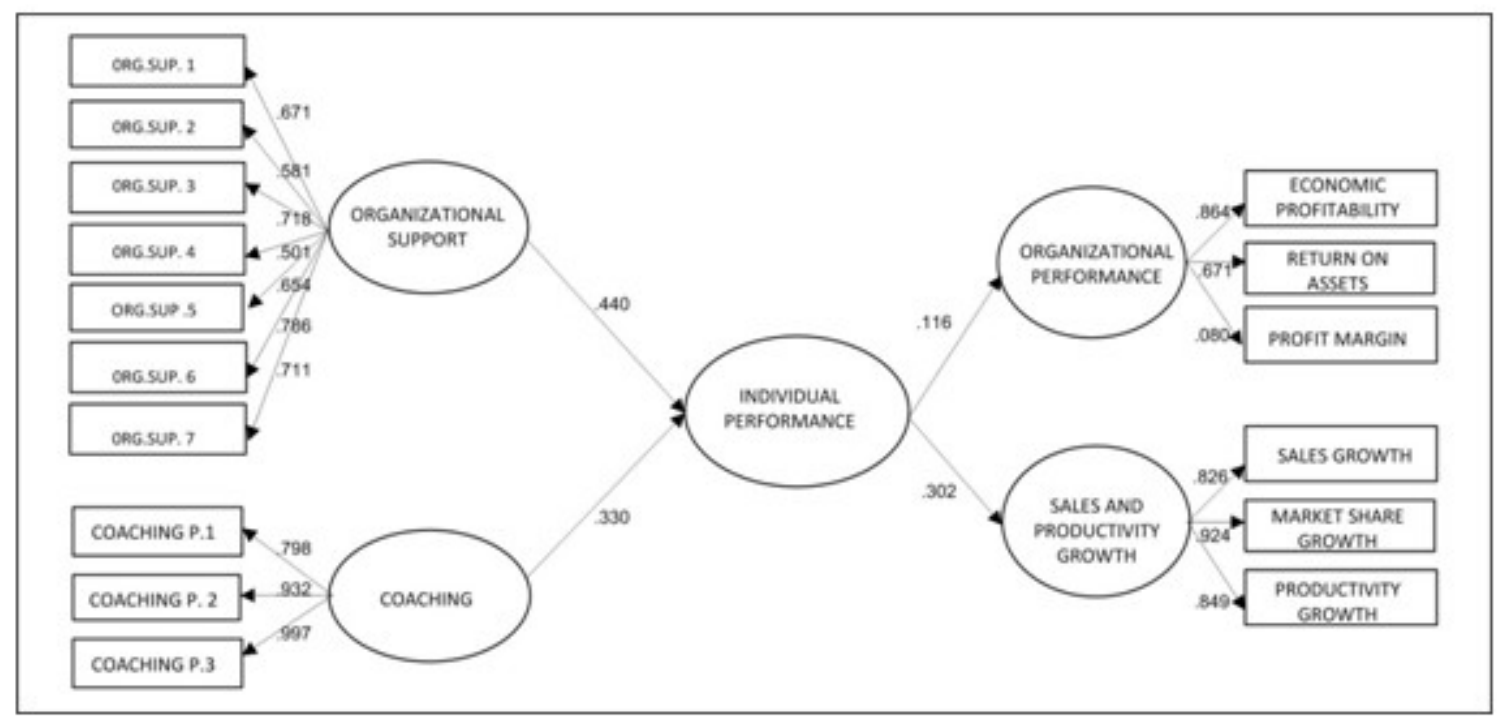

Figure 3. Results of model estimation (standardized solution)

To confirm that the model has an acceptable fit, we examine the goodness-of-fit indices of the multidimensional structural model. The results show a good fit according to the usual criteria (Kline, 2005; McDonald \& Ho, 2002): the Satorra-Bentler scaled $\chi^{2}=167.7799$, with 171 degrees of freedom and $p=0.1155$. Other commonly used indices are as follows: NNFI $=0.971$, $\mathrm{CFI}=0.975, \mathrm{IFI}=0.976, \mathrm{MFI}=0.933$ and RMSEA $<0.03$. The matrix of standardised residuals does not show the need to make any additional changes. All of the modification indicators of the model are low, which suggests that neither adding nor removing any relationships will improve the fit. Retaining the existing model thus avoids capitalising on chance and maintains model parsimony, as Barret (2007) and Goffin (2007) recommend. Based on the goodness-offit indices reported above, we can conclude that the global fit is good and that the errors are at acceptable levels. Examining the individual results, we observe that all of the relationships are significant at a confidence level of $95 \%(t>1.96)$.

The coefficient linking organisational support with individual performance is positive $(0.440)$, thereby confirming Hypothesis 1, which postulates that organisational support has a positive effect on human resources performance. The coefficient linking the coaching process with individual performance is 0.330 , which confirms Hypothesis 2 (the effect of coaching on individual performance).

Similarly, the coefficient of the relationship between individual performance and organisational performance is 0.116 , which confirms Hypothesis 3 . Thus, a positive relationship exists between improvements in individual performance as a result of coaching and organisational 
performance, as measured by economic profitability, return on assets and profit margin. Finally, the results also offer support for Hypothesis 4: the coefficient linking improvements in individual performance as a result of coaching with sales and productivity growth equals 0.302 in the standardised solution.

\section{Discussion}

The first contribution of the current work is its novel incorporation of theoretical support for the implementation of the coaching process, which enriches and complements the existing model. This theoretical support enabled us to explain how firms should develop coaching processes to improve their human resources and to justify the utility for businesses and workers. Thus, we believe that our work identifies a method by which research can progress with respect to this issue. Specifically, social exchange theory explains the exchanges that occur between coach and coachee throughout the process, in which reciprocity appears and a series of transactions occurs between both parties. This relationship reciprocity is an expectation that both participants share and serves as a moral norm of action.

In the first part of this work, we presented coaching as a process of improvement that develops and improves the skills of coachees and whose core is the relationship that participants establish during the process. The second contribution of this work is related to the effects of organisational support and the coaching process on the individual performance of coachees. The transactions that occur during the coaching process generate a number of benefits and costs for those involved in such a relationship. According to our research results, we can conclude that when the coaching process is conducted according to the criteria proposed here, both the coach and coachee perceive important benefits, and the coachees demonstrates improved individual performance, as Hypotheses 1 and 2 postulate.

The third contribution of this work is that it provides insight into the question of whether this improvement in individual performance as a result of coaching has an effect on organisational performance, sales increases and productivity growth. We study these relationships from the most recent perspective of the RBV. Coaching processes confer on individuals a number of attributes that are converted into valuable capital for firms, making it difficult for competitors to imitate or copy them and thus making the competitive advantage generated more sustainable. These research results provide evidence that the individual benefits derived from the coaching process will translate into benefits for organisations because individual benefits indeed have an effect on organisational performance, sales increases and productivity growth, as Hypotheses 3 and 4 postulate. Consequently, on the basis of this theoretical framework and 
our empirical results, we can confirm that coaching processes potentially improve both individual and organisational performance. In making this claim, we have avoided making inferences from one level to the next that could lead to errors.

\subsection{Managerial implications}

The rapid expansion of coaching in firms means that the practice is often conducted in ways that cannot guarantee its effectiveness, giving rise to an effect that is similar to what Woodside (2011) calls "incompetence training" and that we call "incompetence coaching". In a previous study, Hutchinson and Purcell (2010) find that slightly less than half of coaches are satisfied with coaching. The process can fail, with consequent costs for both the participants and the firm. After conducting rigorous research, we have designed a model that firms can use to help them implement coaching processes successfully. We analysed the conditions and factors of the coaching process that are necessary to ensure its effectiveness.

Our results enable us to conclude that coaching processes are a useful tool for developing professionals in organisations, as we found an effect on the performance of human capital. Coaching also helps firms improve their competitive position via effects on organisational performance, sales increases and productivity growth. With the effectiveness of such coaching empirically supported, the next step is to determine how best to conduct the process. As we stated in the theoretical framework section, firms should plan coaching in detail, including the objectives to be pursued. Participants should be given opportunities to develop and achieve promotions, and the process should improve their decision making. To ensure the success of the process, the exchange between the coach and coachee should be positive, with both participants perceiving the benefits to outweigh the costs. Thus, an organisation must strive to maximise benefits and minimise costs. One of the critical points is the selection of participants; specifically, firms should closely examine a coach's profile. The coach should know the organisation well, and his/her personal characteristics should suit those of the coachee in aspects such as the equivalence of professional status, personal affinities and the level of commitment to the process. In particular, the coachee must be an employee with the potential to develop professionally and thus to fully exploit the benefits of the process, work hard throughout the process and trust the coach. Selecting the appropriate participants and providing the proper facilities will limit socio-emotional conflicts and lower opportunity costs on both sides, which will increase the perceived net benefits of the process (i.e., ensure its success). Improvements in a coachee's individual performance will translate into better performance in his/her daily work in the firm, which will positively affect his/her organisation's performance, sales and productivity growth. 


\subsection{Limitations and future lines of research}

This work suffers from a number of limitations that need to be considered to be able to interpret its conclusions appropriately. We now present these limitations, along with the future lines of research that they open up. Our main data collection instrument was the questionnaire, and this suffers from the limitation of subjectivity. The information obtained could be biased because many items are based on respondents' perceptions. Another limitation is that the research is cross-sectional in nature, in other words we obtained the information at a particular moment in time. Future work should analyze the effect of coaching on individual and organizational performance over a period of time using longitudinal analysis. This would isolate temporal phenomena and specific circumstances that can distort the results of the research. In particular we would advise measuring the impact of coaching on organizational performance in the medium to long term. This line of research could use autoregressive longitudinal structural models, which explain the evolution of the variance over time, or MIMIC models, in which the indicators of the latent variables can be longitudinal.

The scope of analysis of this work comprises the different sectors of the Spanish economy. Researchers could replicate this study in specific sectors. This could enrich the analysis because it would limit external influences on performance. Researchers could compare their results to ours, and compare the results between different sectors.

\section{Conclusions}

We draw upon Joo's (2005) conceptual model to analyse the effects of coaching in employees and organizational performance. This work strengthens that framework by incorporating two theoretical approaches: social exchange theory, which helps explain individual outcomes of the coaching process, and the RBV, which helps explain the link with organisational performance. In this way, our research allows to shed light about the benefits of coaching, both for the individuals that participate in the coaching process as well for the organisation. These results provide an additional point of view to managers in order to appraisal the benefits of the coaching process in a wider consideration, both for individuals and firms. On one hand, managers can realise the benefits of the coaching process for the coachees, which contribute to take advantage of the potential of the human resources of the firm. On the other hand, a relevant contribution of this paper is the positive effect of coaching process in the organisation, which can be measured in terms of firm performance and growth. Obviously, these benefits of coaching process are not reached in every company as a universal rule, because of the costs of the process that must be overcome by the benefits. In this sense, we offer some 
recommendations in order to an adequate management of the coaching process, as a way to reduce the risk of failure.

The results here show that coaching processes are an important tool for improving the individual-level performance of human resource. Furthermore, the firms can benefit from the resulting effects on organisational performance, sales increases and productivity growth.

\section{References}

AGARWAL, R.; ANGST, C.; MAGNI, M. (2009). The performance effects of coaching: a multilevel analysis using hierarchical linear modeling. The International Journal of Human Resource Management, 20(10): 2110-2134. http://dx.doi.org/10.1080/09585190903178054

ALLEN, T.D.; SMITH, M.A.; O'SHEA, P.G.; MAEL, F.A.; EBY, L.T. (2009). Organization-level mentoring and organizational, performance within substance abuse centers. Journal of Management, 35: 1113-1128. http://dx.doi.org/10.1177/0149206308329969

AMIT, R.; SCHOEMAKER, P. (1993). Strategic assets and organizational rent. Strategic Management Journal, 14: 33-46. http://dx.doi.org/10.1002/smj.4250140105

ANDERSON, V.; RAYNER, C.; SCHYNS, B. (2009). Coaching at the sharp end: the role of line managers in coaching at work. London: Chartered Institute of Personnel and Development [CIPD].

BAGOZZI, R.P.; YI, Y. (1988). On the evaluation of structural equation models. Journal of Academy of Marketing Science, 16(2): 79-94. http://dx.doi.org/10.1007/BF02723327

BACKES-GELLNER, U.; TUOR, S.N. (2010). Avoiding labor shortages by employer signaling: on the importance of good work climate and labor relations. Industrial and Labor Relations Review, 63: 271.

BARNEY, J.B. (1991). Firm resources and sustained competitive advantage. Journal of Management, 17: 99-110. http://dx.doi.org/10.1177/014920639101700108

BARRET, P. (2007). Structural Equation Modeling: Adjusting Model Fit. Personality and Individual Differences, 42(5): 815-824. http://dx.doi.org/10.1016/j.paid.2006.09.018

BIRDI, K.; CLEGG, C.; PATTERSON, M.; ROBINSON, A.; STRIDE, D.; WALL, T. et al. (2008). The impact of human resource and operational management practices on company productivity: a longitudinal study. Personnel Psychology, 61(3): 467-501. http://dx.doi.org/10.1111/j.1744-6570.2008.00136.x

BOLCH, M. (2001). Proactive coaching. Training, 38(5): 58-66. 
BONO, J.; PURVANOVA, R.K.; OWLER, A.J.; DAVID, B. (2009). A survey of executive coaching practices. Personnel Psychology, 62(2): 361-404.

http://dx.doi.org/10.1111/j.1744-6570.2009.01142.x

BOWLES, S.; CUNNINGHAM, C.J.L.; ROSA, G.M.D.; PICANO, J. (2007). Coaching leaders in middle and executive management: goals, performance, buy-in. Leadership and Organization Development Journal, 28(5): 388. http://dx.doi.org/10.1108/01437730710761715

BOYATZIS, R.E.; SMITH, M.; BLAIZE, N. (2006). Developing sustainable leaders through coaching and compassion. Academy of Management Journal on Learning and Education, 5(1): 8-24. http://dx.doi.org/10.5465/AMLE.2006.20388381

CAREY, W.; PHILIPPON, D.J.; CUMMINGS, G.G. (2011). Coaching models for leadership development: An integrative review. Journal of Leadership Studies, 5(1): 51-69. http://dx.doi.org/10.1002/jls.20204

CARLSON, D.S.; UPTON, N.; SEAMANS, S. (2006). The impact of human resources practices and compensation design on performance: An analysis of family-owned SME'S. Journal of Small Business Management, 44(4): 531-543. http://dx.doi.org/10.1111/j.1540-627X.2006.00188.x

CHAND, M.; KATOU, A. (2007). The impact of HRM practices on organizational performance in the Indian hotel industry. Employee Relations, 29(6): 576-594.

http://dx.doi.org/10.1108/01425450710826096

CHONG, E. (2008). Managerial competency appraisal: A cross-cultural study of American and East Asian managers. Journal of Business Research, 61(3): 191-200. http://dx.doi.org/ 10.1016/j.jbusres.2007.06.007

COLOMO, R.; CASADO, C. (2006). Mentoring y Coaching. It perspective. Journal of Technology Management and Innovation, 3: 131-139.

COMBS, J.; HALL, A.; KETCHEN, D. (2006). How much do high performance work practices improve establishment-level outcomes?. Personnel Psychology, 59, 501-528.

http://dx.doi.org/10.1111/j.1744-6570.2006.00045.x

COOK, K.; EMERSON, R.M. (1978). Power, Equity and Commitment in Exchange Networks. American Sociological Review, 43: 721-739. http://dx.doi.org/10.2307/2094546

CROPANZANO, R.; MITCHELL, M.S. (2005). Social Exchange Theory: An Interdisciplinary Review. Journal of Management, 31(6): 874-900. http://dx.doi.org/10.1177/0149206305279602

DATTA, D.K.; GUTHRIE, J.P.; WRIGHT, P.M. (2005). Human resource management and labor productivity: does industry matter?. Academy of Management Journal, 48(1): 135-152. http://dx.doi.org/10.5465/AMJ.2005.15993158 
DIEDRICH, R. (1996). An iterative approach to executive coaching. Consulting Psychology Journal, 48(2): 61-66. http://dx.doi.org/10.1037/1061-4087.48.2.61

ELLINGER, A.D.; ELLINGER, A.E.; KELLER, S. (2003). Supervising coaching behavior, employee satisfaction and warehouse employee performance. Human Resource Development Quarterly, 14(4): 435-458. http://dx.doi.org/10.1002/hrdq.1078

ELY, K.; ZACCARO, S.J. (2010). Evaluating the Effectiveness of Coaching: A Focus on Stakeholders, Criteria, and Data Collection Methods. In G. Hernez-Broome \& L. Boyce (Eds.). Advancing Executive Coaching (pp. 317-349). San Francisco: Jossey-Bass. http://dx.doi.org/10.1002/9781118255995.ch12

EMERSON, R.M. (1962). Power-dependence relations. American Sociological Review, 27(1): 31-41. http://dx.doi.org/10.2307/2089716

EVERED, R.D.; SELMAN, J.C. (1989). Coaching and the art of management. Organizational Dynamics, 18(2): 16-32. http://dx.doi.org/ 10.1016/0090-2616(89)90040-5

FELDMAN, D.; LANKAU, M.J. (2005). Executive Coaching: A Review and Agenda for Future Research. Journal of Management, 31(6): 829-848. http://dx.doi.org/ 10.1177/0149206305279599

GIL, A; CARRILLO, F. (2013). La creación de conocimiento en las organizaciones a partir del Aprendizaje. Intangible Capital, 9(3): 730-753. http://dx.doi.org/10.3926/ic.418

GOFFIN, R.D. (2007). Assessing the Adequacy of Structural Equation Models: Golden Rules and Editorial Policies. Personality and Individual Differences, 42(5): 831-839.

http://dx.doi.org/10.1016/j.paid.2006.09.019

GOULD, D. (1997). Developing directors through personal coaching. Long Range Planning, 30(1): 29-37. http://dx.doi.org/10.1016/S0024-6301(96)00093-3

GOULDNER, A.W. (1960). The norm of reciprocity: A preliminary statement. American Sociological Review, 25: 161-178. http://dx.doi.org/10.2307/2092623

GRANT, R. (1996). Toward Knowledge based theory of the firm. Strategic Management Journal, 17: 109-122. http://dx.doi.org/10.1002/smj.4250171110

GRAVINA, N.; SIERS, P. (2011). Square Pegs and Round Holes: Ruminations on the Relationship Between Performance Appraisal and Performance Management. Journal of Organizational Behavior Management, 31(4): 277-287.

http://dx.doi.org/10.1080/01608061.2011.619418

GRAY, D.E.; EKINCI, Y.; GOREGAOKAR, H. (2011a). A Five-dimensional Model of Attributes: Some precursors of executive coach selection. International Journal of Selection and Assessment, 19(4): 415-428. http://dx.doi.org/10.1111/j.1468-2389.2011.00569.x 
GRAY, D.E.; EKINCI, Y.; GOREGAOKAR, H. (2011b). Coaching SME managers: business development or personal therapy? A mixed methods study. The International Journal of Human Resource Management, 22(4): 863-882. http://dx.doi.org/10.1080/09585192.2011.555129

GURAV, A.M.; MUDALKAR, P.K. (2011). A Critical Study of Human Resource Practices in Selected Sugar Factories. IUP Journal of Management Research, 10(1): 46.

HAMMERVOLL, T. (2011). Managing interaction for learning and value creation in exchange relationships. Journal of Business Research. http://dx.doi.org/10.1016/j.jbusres.2011.05.011

HANNAFEY, F.T.; VITULANO, L.A. (2013). Ethics and executive coaching: An Agency Theory Approach. Journal of Business Ethics, 115(3): 599-604. http://dx.doi.org/10.1007/s10551-012$1442-z$

HODGETTS, W.S. (2002). Executive coaching: what can go wrong (and how to prevent it). In C. Fitgerald and J. G. Berger (Eds.), Executive Coaching: Practices and Perspectives. Palo Alto, C.A.: Davies-Black.

HUSELID, M.A. (1993). The impact of environmental volatility on human resource planning and strategic human resource management. Human Resources Planning, 16(3): 35.

HUSELID, M.A.; BECKER, B.E.; BEATTY, R. (2005). The workforce scorecard: Managing human capital to execute strategy. Boston: Harvard Business School Press.

HUTCHINSON, S.; PURCELL, J. (2010). Managing ward managers for roles in HRM in the NHS: overworked and under-resourced. Human Resource Management Journal, 20(4): 357-374. http://dx.doi.org/10.1111/j.1748-8583.2010.00141.x

JONES, G.; SPOONER, K. (2006). Coaching high achievers. Consulting Psychology Journal, 58(1): 40-50. http://dx.doi.org/10.1037/1065-9293.58.1.40

JOO, B.K. (2005). Executive Coaching: A Conceptual Framework From an Integrative Review of Practice and Research. Human Resource Development Review, 4(4): 462-488. http://dx.doi.org/10.1177/1534484305280866

KAMPA-KOLESCH, S.; ANDERSON, M.Z. (2001). Executive coaching: A comprehensive review of the literature. Consulting Psychology Journal, 53(4): 205-228. http://dx.doi.org/10.1037/10614087.53.4.205

KLINE, R.B. (2005). Principles and practice of structural equation modeling. New York: Guilford.

LEISINK, P.; KNIES, E. (2011). Line managers' support for older workers. The International Journal of Human Resource Management, 22(9): 1902-1917.

http://dx.doi.org/10.1080/09585192.2011.573969 
LORENZET, S.; COOK, R.; OZEKI, C. (2006). Improving performance in very small firms through effective assessment and feedback. Education and Training, 48(8/9): 568-583. http://dx.doi.org/10.1108/00400910610710010

LOTFIZADEH, A.; EDWARDS, T.; POLING, A. (2014) Motivating Operations in the Journal of Organizational Behavior Management: Review and Discussion of Relevant Articles. Journal of Organizational Behavior Management, 34(2): 69-103.

http://dx.doi.org/10.1080/01608061.2014.914010

LUTHANS, F.; PETERSON, S.W. (2003). 360-degree feedback with systematic coaching: Empirical analysis suggests a winning combination. Human Resource Management, 42(3): 243-256. http://dx.doi.org/10.1002/hrm.10083

MCCRACKEN, M.; WALLACE, M. (2000). Towards a redefinition of strategic HRD. Journal of European Industrial Training, 24(5): 425-436. http://dx.doi.org/10.1108/03090590010354344

MCCRACKEN, M.; HEATON, N. (2012). From 'tucked away' to 'joined at the hip': understanding evolving relationships within the HRBP model in a regional energy company. Human Resource Management Journal, 22(2): 182-198. http://dx.doi.org/10.1111/j.1748-8583.2010.00150.x

MCDONALD, R.P.; HO, M.H. (2002). Principles and practice in reporting structural equation analyses. Psychological Methods, 7: 64-82. http://dx.doi.org/10.1037/1082-989x.7.1.64

MOEN, F.; ALLGOOD, E. (2009). Coaching and the Effect on Self-efficacy Organization Development Journal, 27(4): 69.

MOLINA, J.F.; CLAVER, E.; PEREIRA, J.; TARÍ, J.J. (2009). Gestión de la calidad y medioambiental y rendimiento de los hoteles españoles. Revista Europea de Dirección y Economía de Empresa, 18(2): 63-78.

NÚÑEZ-CACHO, P.; GRANDE, F.A.; PEDROSA, C. (2012). New challenges in career development: the boundaryless career model. Universia Business Review, 34(1): 14-35.

NÚÑEZ-CACHO, P.; GRANDE， F. (2012). The human resources development through mentoring: The Spanish case. Intangible Capital, 8(1), 61-91. http://dx.doi.org/10.3926/ic.292

OLIVERO, G.; BANE, D.; KOPELMAN, R.E. (1997). Executive coaching as transfer of training tool: effects on productivity in public agency. Public Personnel Management, 26(4): 120-134.

PARKER, P.; HALL, D.T.; KRAM, K.E. (2008). Peer Coaching: A Relational Process for Accelerating Career Learning. Academy of Management Learning and Education, 7(4): 487-503. http://dx.doi.org/10.5465/AMLE.2008.35882189

PATTERSON, M.; WEST, M.A. (2004). Integrated manufacturing, empowerment and company performance. Journal of Organizational Behavior, 25: 641-665. http://dx.doi.org/10.1002/job.261 
PETERAF, M.A. (1993). The cornerstones of competitive advantage: a resource based view. Strategic Management Journal, 14(3): 179-191. http://dx.doi.org/10.1002/smj.4250140303

PETERSON, R.A. (1994). A meta-analysis of Cronbach's coefficient alpha. Journal of Consumer Research, 21: 381-391. http://dx.doi.org/10.1086/209405

PÉREZ, S.; MONTES, J.M.; VÁZQUEZ, C. (2006). Human Resource Management as a Determining Factor in Organizational Learning. Management Learning, 37(2): 215. http://dx.doi.org/10.1177/1350507606063443

RICHARD, O.C.; TAYLOR, E.C.; BARNETT, T.; NESBIT, M.F. (2002). Procedural voice and distributive justice: their influence on mentoring career help and other outcomes. Journal of Business Research, 55(9): 725-735. http://dx.doi.org/10.1016/S0148-2963(00)00183-1

ROWOLD, J.; SCHILLING, J. (2006). Career-related continuous learning. Career Development International, 11(6): 489. http://dx.doi.org/10.1108/13620430610692917

RUTHEFORD, M.W.; KURATKO, D.F.; HOLT, A.T. (2008). Examining the Link Between "Familiness" and Performance: Can the F-PEC Untangle the Family Business Theory Jungle?. Entrepreneurship Theory and Practice, 32(6): 1089-1109. http://dx.doi.org/10.1111/j.15406520.2008.00275.x

SAKS, A.M.; GRUMAN, J.A. (2011). Organizational socialization and positive organizational behaviour: implications for theory, research, and practice. Canadian Journal of Administrative Sciences / Revue Canadienne des Sciences de l'Administration, 28: 14-26.

SALINERO, Y.; MUÑOZ, R. (2007). ¿Como se desarrolla la práctica de formación en las empresas? Una aproximación al caso de Castilla-La Mancha. Universia Business Review, 16: 64-85.

SEGERS, J.; VLOEBERGHS, D.; HENDERICKX, E.; INCEOGLU, I. (2011). Structuring and understanding the coaching industry: The Coaching Cube. Academy of Management Learning \& Education, 10: 204-221. http://dx.doi.org/10.5465/AMLE.2011.62798930

SHERMAN, S.; FREAS, A. (2004). The wild west of executive coaching. Harvard Business Review, 82(1): 82-90.

SHIH, H.-A.; CHIANG, Y.-H.; CHEN, T.-J. (2012). Transformational leadership, trusting climate, and knowledge-exchange behaviors in Taiwan. The International Journal of Human Resource Management, 23(6): 1057-1073. http://dx.doi.org/10.1080/09585192.2011.639546

TEPPER, B.J.; TAYLOR, E.C. (2003). Relationships among supervisors' and subordinates' procedural justice perceptions and organizational citizenship behaviors. Academy of Management Journal, 46: 97-105. http://dx.doi.org/10.2307/30040679 
WANBERG, C.R.; WELSH, E.T.; HEZLETT, S.A. (2003). Mentoring research: A review and dynamics process model. Research in Personnel and Human Resources Management, 22: 39-124. http://dx.doi.org/10.1016/S0742-7301(03)22002-8

WOODSIDE, A. (2011). Incompetency training: Theory, practice, and remedies. Journal of Business Research, 65(3): 279-293. http://dx.doi.org/10.1016/j.jbusres.2011.10.025

ZALESKA, K.; DE MENEZES, L. (2007). Human resources development practices and their association with employee attitudes: Between traditional and new careers. Human Relations, 60(7): 987-1018. http://dx.doi.org/10.1177/0018726707081155

ZEUS, P.; SKIFFINGTON, S. (2002). Guía completa de coaching en el trabajo. Madrid: Mc Graw Hill. 